\title{
Sedimentary Environments Can Be Changed by Geotechnology (Case Study: A Morphotectonic Idea for Design of Extensive Artificial Bay on the Iranian Plateau)
}

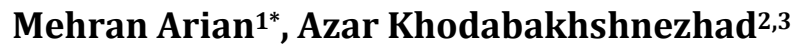 \\ ${ }^{1}$ Department of Geology, Science and Research Branch, Islamic Azad University, Tehran, Iran \\ ${ }^{2}$ Department of Education, One Territory of Baharestan Education Office, Ministry of Education, Tehran, Iran \\ ${ }^{3}$ Department of Geology, North Tehran Branch, Islamic Azad University, Tehran, Iran \\ Email: ${ }^{*}$ mehranarian@yahoo.com
}

Received 28 March 2015; accepted 12 May 2015; published 15 May 2015

Copyright (C 2015 by authors and Scientific Research Publishing Inc.

This work is licensed under the Creative Commons Attribution International License (CC BY). http://creativecommons.org/licenses/by/4.0/

(c) (i) Open Access

\begin{abstract}
Iranian Plateau between the Lesser Caucasus-Alborz Mountains on the north and Zagros-Makran Ranges on the south has several inter-mountainous depressions which were filled by Quaternary deposits. Geologic evidence implied that, the last marine conditions in some depressions such as the Dasht-e Kavir, Dasht-e Lut and Jazmourian basins, had been changed to land conditions in middle Miocene. Based on shape and elevation of the Dasht-e Kavir, Dasht-e Lut and Jazmourian plains related to sea level and geomorphology of Iranian plateau, three semi-connective artificial lakes can be constructed upon the mentioned plains by consideration of many geologic and geotechnical parameters. These artificial lakes can feed by pumping of water from Oman Sea and form a triple artificial bay which they must be connected together by two gated straits. Therefore, a possible morphotectonic idea with many advantages has suggested that it can be present as an international geotechnologic design. This design has the important environmental impacts which can be changed desert to lake sedimentary basins.
\end{abstract}

\section{Keywords}

Environments, Geotechnology, Artificial Bay, Sedimentary Basin, Quaternary Deposits, Central Iran

\footnotetext{
"Corresponding author.
}

How to cite this paper: Arian, M. and Khodabakhshnezhad, A. (2015) Sedimentary Environments Can Be Changed by Geotechnology (Case Study: A Morphotectonic Idea for Design of Extensive Artificial Bay on the Iranian Plateau). International Journal of Geosciences, 6, 487-496. http://dx.doi.org/10.4236/ijg.2015.65039 


\section{Introduction}

Geotechnology is a branch of engineering and science that is concerned with construction in or on the ground. It deals with the study of subsurface conditions and materials through soil and rock mechanics, of the stability of slopes, seismicity and etc.

Five thousand years ago, the craters of extinct volcanoes in Arabia were used as reservoirs by farmers for their irrigation water [1]. Artificial lakes or man-made dating to the 5th century BC have been found in ancient Greece [2]. In this study, a morphotectonic idea with many advantages has suggested that it can be present as an international geotechnologic design. This design has the important environmental impacts which can be changed desert to lake sedimentary basins.

\section{Materials and Methods}

\subsection{Microclimate}

Iran is the eighteenth largest country in the world, with an area of 1,648,195 $\mathrm{km}^{2}$. Its area roughly equals that of the United Kingdom, France, Spain, and Germany combined. Iran lies between latitudes $24^{\circ}$ and $40^{\circ} \mathrm{N}$, and longitudes $44^{\circ}$ and $64^{\circ} \mathrm{E}$. Its borders are with Azerbaijan and Armenia to the north-west; the Caspian Sea to the north; Turkmenistan to the north-east; Pakistan and Afghanistan to the east; Turkey and Iraq to the west; and finally the waters of the Persian Gulf and the Gulf of Oman to the south.

Iran consists of the Iranian Plateau with the exception of the coasts of the Caspian Sea and Khuzestan Province. It is one of the world's most mountainous countries, its landscape dominated by rugged mountain ranges that separate various basins or plateau from one another. The populous western part is the most mountainous, with ranges such as the Lesser Caucasus, Zagros and Alborz Mountains; the last contains Iran's highest point, Mount Damavand at $5671 \mathrm{~m}$.

The northern part of Iran is covered by dense rain forests called North or the Jungles of Iran. The eastern part consists mostly of desert basins such as the Dasht-e Kavir or Great Kavir Basin (Figure 1), Iran's largest desert, in the north-central portion of the country, and the Dasht-e Lut (Figure 2), in the east, as well as some salt lakes. This is because the mountain ranges are too high for rain clouds to reach these regions. The only large plains are found along the coast of the Caspian Sea and at the northern end of the Persian Gulf, where Iran borders the mouth of the Arvand Rod River. Smaller, discontinuous plains are found along the remaining coast of the Persian Gulf, the Strait of Hormuz and the Gulf of Oman.

Iran's climate ranges from arid or semiarid, to subtropical along the Caspian coast and the northern forests. On the northern edge of the country (the Caspian coastal plain) temperatures rarely fall below freezing and the

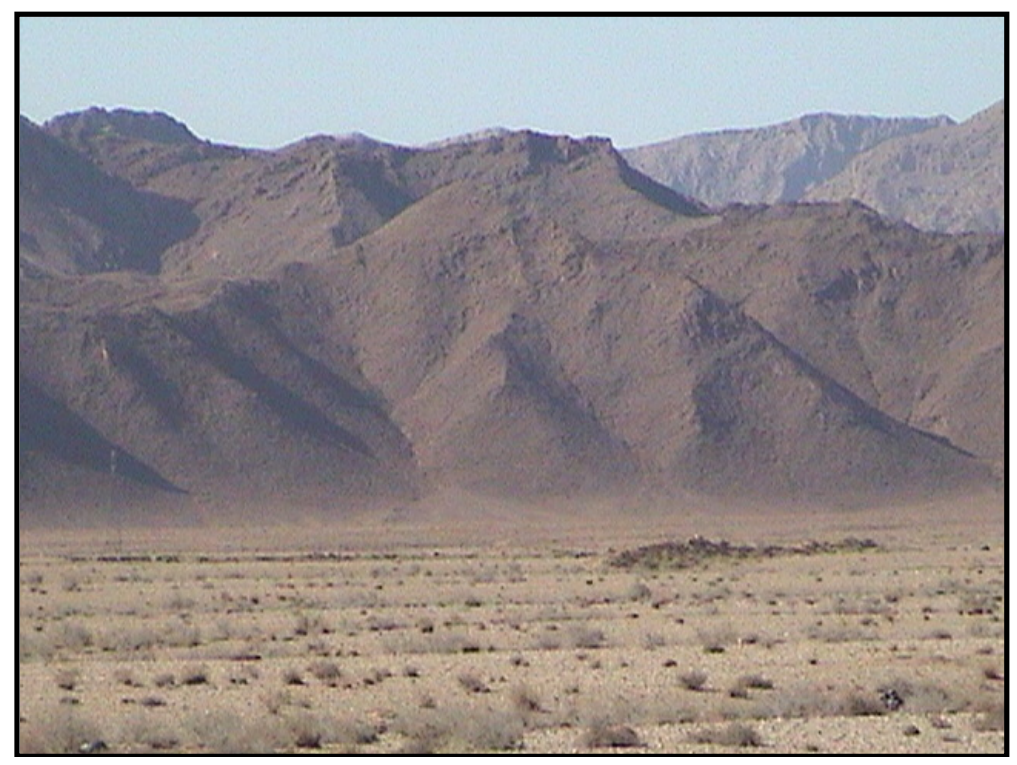

Figure 1. A northward view from the northern border of Dasht-e Kavir. 


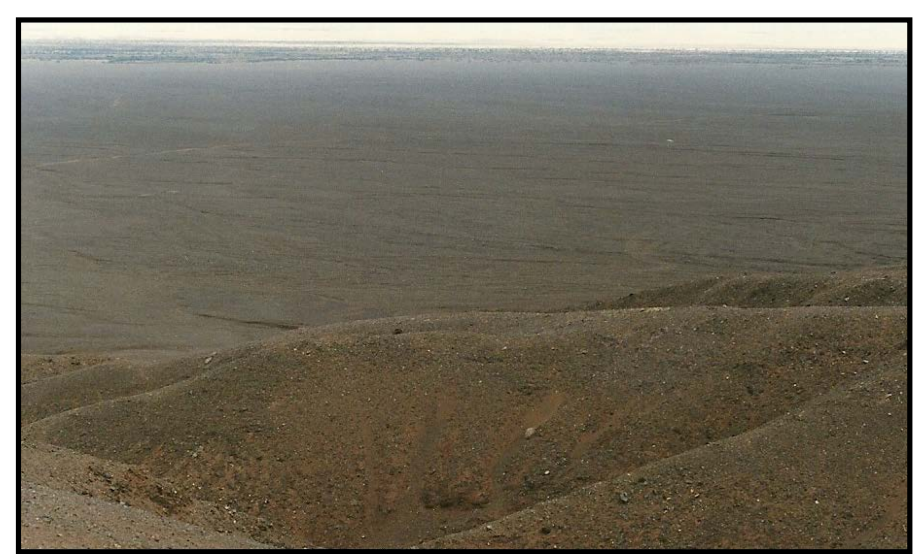

Figure 2. A northward view from the southern border of Dasht-e Lut.

area remains humid for the rest of the year. Summer temperatures rarely exceed $29^{\circ} \mathrm{C}$. Annual precipitation is $680 \mathrm{~mm}$ in the eastern part of the plain and more than $1700 \mathrm{~mm}$ in the western part.

To the west, settlements in the Zagros basin experience lower temperatures, severe winters with below zero average daily temperatures and heavy snowfall. The eastern and central basins are arid, with less than $200 \mathrm{~mm}$ of rain, and have occasional deserts. Average summer temperatures exceed $38^{\circ} \mathrm{C}$. The coastal plains of the Persian Gulf and Gulf of Oman in southern Iran have mild winters, and very humid and hot summers. The annual precipitation ranges from 135 to $355 \mathrm{~mm}$.

\subsection{Tectonics of Central Iran}

Central Iran, during the Paleozoic Era, had the form of a plateau, and then during the Mesozoic and Cenozoic Eras, was transformed to a highly active region; in which sedimentation was accompanied by volcanic activity with associated penetration of intrusive bodies. Central Iran basins are located in the eastern part of the Iranian plateau [3]. The plateau is one of two main plateau in the Alpine-Himalayan collision system [4] [5], the other being Tibet [6]. It extends from eastern Anatolia to eastern Iran, and typically has elevations until 2 km above mean sea level.

The basement of the plateau consists of microcontinents that were accreted to each other and Eurasia by the Late Cretaceous or early Tertiary [7], interspersed with zones of Ophiolite and mélanges. Volcanism of late Cretaceous-early Miocene age in Central Iran represent Andean type magmatism in southern Eurasia during the Neo-Tethyan subduction. Volcanic and turbidite successions up to $5 \mathrm{~km}$ thick represent Eocene back-arc extension across Central Iran, the Alborz and the Lesser Caucasus regions, north of the Neo-Tethyan subduction zone, and prior to Arabia-Eurasia collision [8]. This succession is commonly overlain in Central Iran by terrestrial clastics, evaporites and volcanics of the Lower Red Formation; of Oligocene age [9]. Marine deposition resumed across much of Central Iran with the carbonates of the largely lower Miocene Qom Formation, similar lower Miocene marine strata were deposited across much of Anatolia and the Lesser Caucasus [10]. The Qom Formation pinched out in the north against the southern side of the Alborz and in the south along a line parallel to and $100 \mathrm{~km}$ northeast of the Zagros suture-indicating sub-aerial relief both north and south of the marine basin. The end of marine sedimentation may have been diachronous: the Qom Formation is overlain by middle Miocene terrestrial clastics of the Upper Red Formation [11].

Based on [12], the collision of Arabia and Eurasia was preceded by 175 Million years ago of subduction of Neo-Tethyan oceanic lithosphere. Associated magmatic activity includes Jurassic plutons in the Sanandaj-Sirjan zone of southern Iran, limited Cretaceous magmatism in the Alborz Mountains of northern Iran, and widespread Eocene volcanism across central Iran.

Metamorphic core complexes of Eocene age have recently been recognized in widely separated parts of Iran, suggesting that Tertiary volcanism was related to extension. Geochemical data indicate that Eocene volcanism was typical of continental arcs and was followed by less voluminous Oligocene basaltic volcanism of the type often associated with back-arc basins. This set of observations suggests that mid-Mesozoic plutons in southern Iran are the remnants of an original volcanic arc that was only weakly developed because of slow subduction rate. 
Magmatic activity largely ceased in central Iran during the Cretaceous and shifted to the north, suggesting a period of flat slab subduction. Subsequent slab-rollback during the Eocene extended the overriding plate, forming metamorphic core complexes and inducing pressure-release melting of partially hydrated lithospheric mantle and upwelling of asthenosphere.

Also, based on previous work on the salt diapirism [13]-[22] and neotectonics regime in Iran [23], Zagros in south Iran is the most active zone [24]-[38]. Then, Alborz in north Iran [39]-[70] and Central Iran [70]-[81] have been situated in the next orders.

\subsection{Bedrocks of Central Iran Basins}

Volcanic and turbidities successions of Eocene, Lower Red, Qom and Upper Red Formations are common bedrocks in central Iran basins [82]. This succession is commonly overlain in the Dasht-e Kavir basin by Quaternary terrestrial clastics. But in the Jazmourian (Figure 3) and Dasht-e Lut basins, a volcanic and turbidities succession of Eocene is commonly overlain by Quaternary terrestrial clastics. It means that, the last marine conditions in the Dasht-e Kavir (A in Figure 4), Dasht-e Lut (B in Figure 4) and Jazmourian basins (C in Figure 4) has been overlain by these alluvium deposits (Quaternary terrestrial clastics).

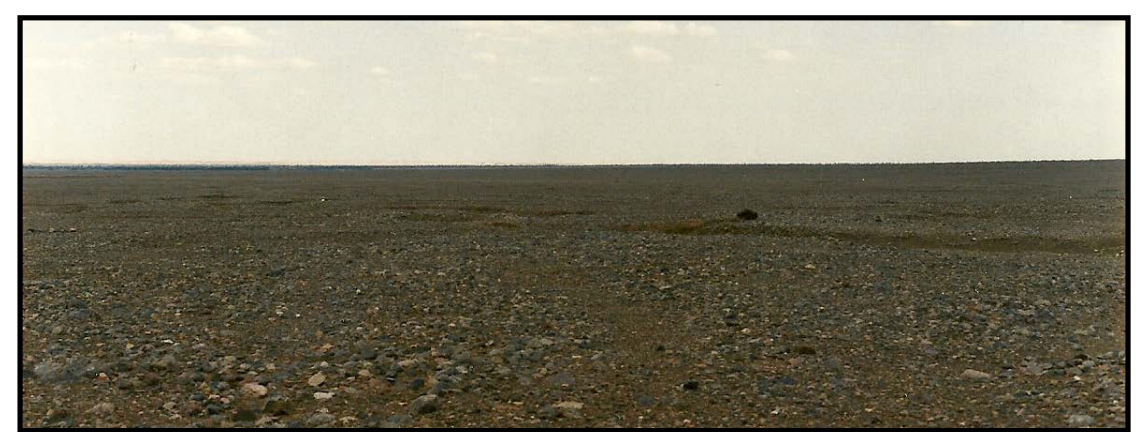

Figure 3. An eastward view from Jazmourian basin.

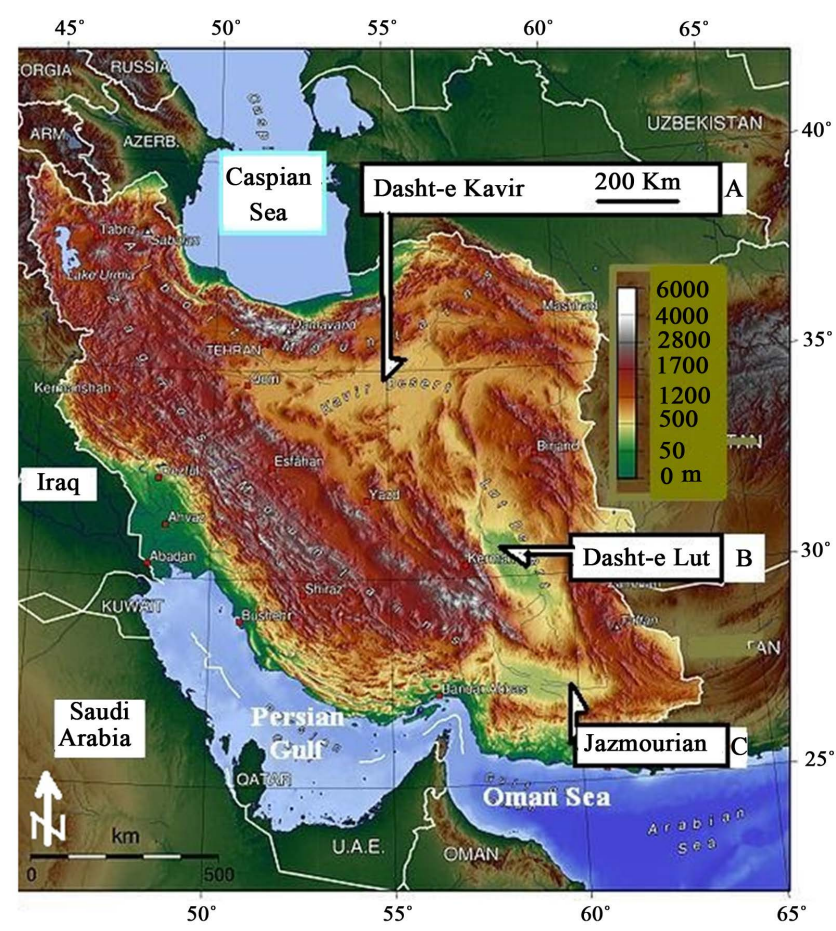

Figure 4. Geographical distribution of three main recent basins in Iran, modified from http://www.worldofmaps.net. 
There is much geologic evidence for existence of epicontinental seas in the last million years. These epicontinental seas were covering the basins on Iran plateau, but they have divided to the several sub-basins by the more uplifting and folding of surrounding areas. Finally, they filled by evaporates and clastic deposits and some separated lakes such as Urmieh and Qum salt lakes have formed in Quaternary period.

An abundance of extensive basins, between individual mountain ranges, is among the outstanding characteristics of Central Iran. The structural plains either are formed over the basins of volcanic basement rocks or are in alignment with the synclines structures and grabens. The mountain ranges, which are extended at this region, are divided by closed and open depressions and plains, at various areas, in different dimensions and forms. A dry bio-climate is prevalent on these plains, so they are called desert plains.

\subsection{Seismicity}

Seismotectonics-geologic hazards zoning map of Iran [83] is based on deterministic seismic hazards evaluation using the seismicity records, structural trends, tectonic settings, fault ruptures and neotectonics activities in Iran.

It contains the earthquake hazards parameters such as b value and Mmax for the nineteen seismotectonic provinces. Zagros and Alborz have deep earthquakes that it is indicator for existence of thick-skinned tectonics.

The most part of study area has situated in Jazmourian, Lut and Great Kavir-Taibad provinces; Dominant structural trend in Jazmourian province is E-W. From tectonics point of view, it contains a fore arc basin (Jazmourian plain) that has been continued to Mashkel plain in Pakistan. Focal mechanisms of many earthquakes are reversed and thrusted and sometimes normal (in related to bending of subducting oceanic lithosphere) such as NW Saravan with $69 \mathrm{Km}$ focal depth (Ms = 5.2, 2009) and SE Khash with $82 \mathrm{Km}$ focal depth $(\mathrm{Ms}=7.7,2013)$. Jazmourian province has moderate earthquakes with middle frequency, medium repeat time and down to 150 $\mathrm{Km}$ focal depth. Intensity of earthquakes is in middle levels by very deep hypocenters.

The most important seismic hazards in Jazmourian province are rapid uplifting and settlement in some plains. It should be noted that low seismicity in Makran and Jazmourian provinces has been related to slow subduction rate and steeper dip of Benioff zone.

Dominant structural trend in Lut province is NW-SE. From tectonics point of view, it contains a retroarc (back arc) basin (Lut plain) that has continued to Helmand plain in Pakistan. Focal mechanisms of many earthquakes are reversed and thrusted and/or right slip in related to N-S strike slip faults such as Nayband and Nehbandan.

Lut province has low earthquakes with low frequency, medium repeat time and down to $10 \mathrm{Km}$ focal depth. Intensity of earthquakes is in high levels by existence of hot igneous rocks. The most important seismic hazards in Lut province that contains Lut plain are settlement, surface faulting and volcanic hazards in southern and western part of plain.

Dominant structural trend in Great Kavir-Taibad province is NW-SE in eastern part and NE-SW in western part. From tectonics point of view, it contains the Maiamay-Taibad marginal back arc basin, south eastern part of Great Kavir-Urmieh lake foreland basin and South Great Kavir folded and thrusted belt. The latter case is result of collision between northern part of East-Central Iran miniplate and south eastern part of North-Central Iran miniplate. Focal mechanisms of many earthquakes are thrusting and dextral strike slip faulting in eastern part and sinistral strike slip faulting and thrusting in western part such as Garmsar (Ms = 5.1, 2007).

Great Kavir-Taibad province has low to moderate earthquakes with low frequency, medium repeat time and down to $10 \mathrm{Km}$ focal depth. Intensity of earthquakes is in low levels. The most important seismic hazards in Great Kavir-Taibad province are settlement in some plains and surface faulting.

\section{Results and Discussion}

Based on geomorphology of Iranian plateau and elevation of some its plain related to sea level, three semi-connective artificial lakes can be construct by consideration of many geologic and geotechnical parameters. These artificial lakes which cover central part of Dasht-e Kavir (A in Figure 5), Dasht-e Lut (B in Figure 5) and Jazmourian (C in Figure 5) basins will feed by pumping of water from Oman Sea in the long periodical times.

The water pumping can be start from the west termination of Makran range (south of Minab) and thus, a triple artificial bay will be form. This bay is composed from three extensive lakes that cover recent Dasht-e Kavir, Dasht-e Lut and Jazmourian basins (Figure 4). The lakes must be connecting together by two gated straits.

In the other hand, seismotectonics provinces such as Jazmourian, Lut and Great Kavir-Taibad that are contain 


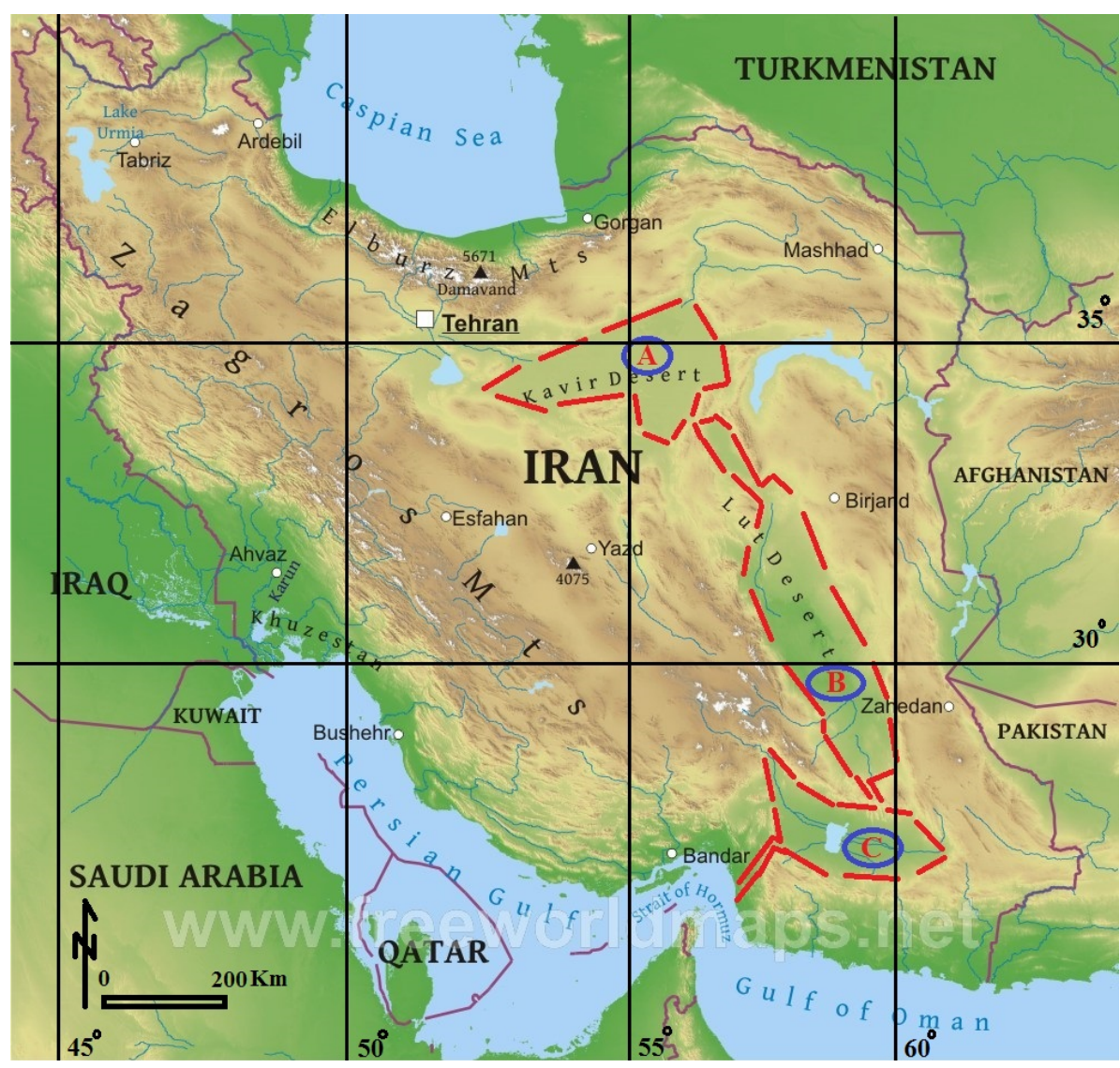

Figure 5. Geographical position of Dasht-e Kavir (A), Dasht-e Lut (B) and Jazmourian (C) basins on the Iranian plateau modified from http://www.freeworldmaps.net.

the most part of study area have not shown high seismic hazards. Because, the most part of deformation in Iran has been concentrated in its continental crust. Lut and Great Kavir-Taibad have not got destructive earthquakes and Jazmorian has got deep earthquakes that it is indicator for slow subduction of Oman Sea.

\section{Conclusions}

A new morphotectonic idea for design of extensive artificial bay on the Iranian plateau was suggested in this paper. This suggestive idea has several advantages: development of marine and desert ecotourism and geotourism; change of seismicity regime from low frequency/high magnitude to high frequency/low magnitude; construction of new cities and touristic villages; construction of natural parks; construction of blocks for migrating fish and trapping them; development of agricultural activities by use of fresh water technology; change of the local climate with increasing humidity and reducing extremes of temperature in local scales.

This design has got the important environmental impacts which can be changed desert to lake sedimentary basins. Also, tectonic setting, geologic position, and seismicity regime are compatible with this suggestive idea. Finally, based on morphotectonic conditions, Dasht-e Kavir, Dasht-e Lut and Jazmourian basins are very suitable to lake formation. The lakes must be connected together by gated straits.

\section{Acknowledgements}

This work has funded by the Department of geology, Islamic Azad University, Science and Research branch, Tehran, Iran. Also, Special thanks to vice-president for research in Science and Research branch, Tehran.

\section{References}

[1] Smith, S. (2006) Water: The Vital Resource. The Open University Worldwide. 
[2] Wilson, N. (2005) Encyclopedia of Ancient Greece. Routledge, London, 832.

[3] Arian, M. (2013) Physiographic-Tectonic Zoning of Iran’s Sedimentary Basins. Open Journal of Geology, 3, $169-177$. http://dx.doi.org/10.4236/ojg.2013.33020

[4] Qorashi, M. and Arian, M. (2011) Tectonics of Iran. Geologic Survey of Iran, 336 p.

[5] Arian, M. (2011) Basement Tectonics and Geology of Iran. Asar Nafis Press, 300 p.

[6] Sengor, A.M.C. and Kidd, W.S.F. (1979) Post-Collisional Tectonics of the Turkish-Iranian Plateau and a Comparison with Tibet. Tectonophysics, 55, 361-376. http://dx.doi.org/10.1016/0040-1951(79)90184-7

[7] Sengor, A.M.C. (1990) A New Model for the Late Palaeozoic-Mesozoic Tectonic Evolution of Iran and Implications for Oman, In: Robertson, A.H.F., Searle, M.P. and Ries, A.C., Eds., The Geology and Tectonics of the Oman Region, Geol. Soc. Spec. Publ., Vol. 49, 797-831. http://dx.doi.org/10.1144/gsl.sp.1992.049.01.49

[8] Brunet, M.F., Korotaev, M.V., Ershov, A.V. and Nikishin, A.M. (2003) The South Caspian Basin: A Review of Its Evolution from Subsidence Modeling. Sedimentary Geology, 156, 119-146. http://dx.doi.org/10.1016/S0037-0738(02)00285-3

[9] Stocklin, J. (1971) Stratigraphic Lexicon of Iran Part 1: Central, North and East Iran. Geological Survey of Iran, Tehran, 338 p.

[10] Toloczyki, M., Trunit, P. and Voges, A. (1994) Geological Map, Sheet F5, Tbilisi, Scale 1:1,500,000. International Geological Congress, Hannover.

[11] Allen, M., Jackson, J. and Walker, R. (2004) Late Cenozoic Reorganization of the Arabia-Eurasia Collision and the Comparison of Short-Term and Long-Term Deformation Rates. Tectonics, 23, 16 p. http://dx.doi.org/10.1029/2003tc001530

[12] Verdel, C. (2008) Cenozoic Geology of Iran: An Integrated Study of Extensional Tectonics and Related Volcanism. PhD Dissertation, California Institute of Technology, Pasadena.

[13] Arian, M. (2011) A Preface on Salt Diapirism of Iran. Asar Nafis Press, 309 p.

[14] Arian, M. and Noroozpour, H. (2015) The Biggest Salt-Tongue Canopy of Central Iran. Open Journal of Geology, 5, 55-60. http://dx.doi.org/10.4236/ojg.2015.52005

[15] Asadian, F., Pourkermani, M. and Arian, M. (2007) Tectonic Geomorphology of Salt Structures in the GarmsarLasjerd Area. Geographical Research, 39, 75-84.

[16] Pourkermani, M. and Arian, M. (1997) Salt Domes of Central Iran. Journal of Humanities University of Sistan and Balouchestan, 3, 29-41.

[17] Arian, M. (2012) Salt Diapirism and Tectonics. 2nd Edition, Asar Nafis Press, 319 p.

[18] Arian, M. and Noroozpour, H. (2015) Tectonic Geomorphology of Iran's Salt Structures. Open Journal of Geology, 5, 61-72. http://dx.doi.org/10.4236/ojg.2015.52006

[19] Asadian, F. and Arian, M. (2009) Identification of Diapiric Provinces of Central Iran through Geological and Geographical Analysis. International Journal of Agriculture Environment \& Biotechnology, 2, 3443-3451.

[20] Arian, M. (2012) Clustering of Diapiric Provinces in the Central Iran Basin. Carbonates and Evaporites, 27, 9-18. http://dx.doi.org/10.1007/s13146-011-0079-9

[21] Pourkermani, M. and Arian, M. (1998) Tectonic Geomorphology of Salt Domes in West of Zanjan Province, Iran. Geographical Research, 47, 44-53.

[22] Arian, M. and Feizi, F. (2010) The Significance of Faulting on the Surficial Spreading of Evaporitic Deposits in the Varamin-Semnan Area. Journal of Earth and Resources, 3, 1-20.

[23] Arian, M. (2011) Middle East Tectonics. 2nd Edition, Asar Nafis Press, 236 p.

[24] Arian, M. and Aram, Z. (2014) Relative Tectonic Activity Classification in the Kermanshah Area, Western Iran. Solid Earth, 5, 1277-1291. http://dx.doi.org/10.5194/se-5-1277-2014

[25] Mashal, M., Kermani, M.P., Charchi, A., Almasian, M. and Arian, M. (2013) Pattern of Structural Geology Underground in Eastern of North Dezfol Embayment. Advances in Environmental Biology, 7, 260-268.

[26] Pazhoohan, M., Arian, M., Ghorashi, M. and Khosrotehrani, K. (2014) A Study of Drainage Pattern Responses to Active Tectonics in Tadvan Region, SW Iran. Geodynamics, 1, 36-41.

[27] Rahimi, N. and Arian, M. (2014) Tectonic Geomorphplogy of Hamedan-Sosangerd Region, West Iran. Advances in Environmental Biology, 8, 119-124.

[28] Arian, M. and Hashemi, A. (2008) Seismotectonic Zoning in the Zagros. Journal of Sciences, 18, 63-76.

[29] Arian, M., Ahmadnia, A., Qorashi, M. and Pourkermani, M. (2002) Structural Analysis of Mengharak Transcurrent Fault System in Zagros, Iran. Special Geo 2002 Conference Issue Geoarabia, 7, 209-210. 
[30] Arian, M., Qorashi, M., Pourkermani, M. and Ahmadnia, A. (2003) Fractal Analysis of Mengharak Transcurrent Fault System in Zagros, in Iran. Abstracts of 4th International Conference on Seismology and Earthquake Engineering, Tehran, 12-14 May 2003, 23.

[31] Baharvand, S., Pourkermani, M., Ajalloian, R., Arian, M. and Nouryazdan, A.R. (2010) Seymareh Landslide and Its Role in Environmental and Geomorphologic Changes of the Pole-Dokhtar Area. Journal of the Earth, 4, 13-24.

[32] Abdideh, M., Qorashi, M., Rangzan, K. and Arian, M. (2011) Assessment of Relative Active Tectonics Using Morphometric Analysis, Case Study of Dez River (Southwestern, Iran). Geosciences Scientific Quarterly Journal, 20, 33-46.

[33] Arian, M., Qorashi, M., Pourkermani, M. and Ahmadnia, A. (2006) The Structural Significance Kareh Bas Transcurrent Fault System in the Zagros Fold and Thrust Belt. Journal of Geosciences, Geological Survey of Iran, 15, 126-133.

[34] Khodabakhshnezhad, A., Arian, M. and Pourkermani, M. (2008) The Elements of Fold Style Analysis in the Asmari anticline (Zagros). Journal of Sciences, 69, 131-140.

[35] Arian, M., Pourkermani, M., Khodabakhshnezhad, A. and Noroozpour, H. (2011) Investigation of Oil Trap in the Asmari Anticline (Zagros, Iran). Indian Journal of Science and Technology, 4, 1696-1699.

[36] Khodabakhshnezhad, A., Arian, M. and Pourkermani, M. (2015) Folding Mechanism in the Asmari Anticline, Zagros, Iran. Open Journal of Geology, 5.

[37] Ehsani, J. and Arian, M. (2015) Quantitative Analysis of Relative Tectonic Activity in the Jarahi-Hendijan Basin Area, Zagros Iran. Geosciences Journal, 19, 1-15. http://10.1007/s12303-015-0016-3 http://dx.doi.org/10.1007/s12303-015-0016-3

[38] Arian, M. and Mohammadian, R. (2011) Analysis of Fractures in the Asmari Reservoir of Marun Oil Field (Zagros). Geosciences, 20, 87-96.

[39] Arian, M., Maleki, Z. and Noroozpour, H. (2011) Cenozoic Diastrophism and Deformational Events in the East Central Alborz. Journal of Basic and Applied Scientific Research, 1, 2394-2400.

[40] Feizi, F., Arian, A. and Rahmani, R. (2007) Seismotectonic Zoning in the Eastern Part of the Central Alborz. Journal of Sciences, 17, 151-164. http://dx.doi.org/10.3923/jas.2009.4115.4126

[41] Khavari, R., Arian, M. and Ghorashi, M. (2009) Neotectonics of the South Central Alborz Drainage Basin, in NW Tehran, N Iran. Journal of Applied Sciences, 9, 4115-4126.

[42] Arian, M. and Bagha, N. (2012) Active Tectonics of Tehran Area, Iran. Journal of Basic and Applied Scientific Research, 2, 3805-3819.

[43] Bagha, N., Arian, M., Ghorashi, M., Pourkermani, M., El Hamdouni, R. and Solgi, A. (2014) Evaluation of Relative Tectonic Activity in the Tehran Basin, Central Alborz, Northern Iran. Geomorphology, 213, 66-87. http://dx.doi.org/10.1016/j.geomorph.2013.12.041

[44] Arian, M. and Feizi, F. (2005) Application of Geomorphic Indices to the Assessment of Relative Tectonic Activity Levels in the Alborz-Central Iran Border Zone (From the East of Varamin to the East of Semnan). Journal of Sciences (Islamic Azad University), 15, 378-403.

[45] Arian, M., Bagha, N., Khavari, R. and Noroozpour, H. (2012) Seismic Sources and Neo-Tectonics of Tehran Area (North Iran). Indian Journal of Science and Technology, 5, 2379-2383.

[46] Moghimi, H., Arian, M. and Sorbi, A. (2015) Fault Movement Potential of Marzanabad Area, North Alborz, Iran. Open Journal of Geology, 5, 126-135. http://dx.doi.org/10.4236/ojg.2015.53012

[47] Arian, M. and Pourkermani, M. (2004) Tectonic Elements of South Flank in the East-Central Alborz Mountain. Journal of Sciences, Teacher Training University, 4, 359-368.

[48] Arian, M. and Qorashi, M. (2006) The Movement Potential Evaluation of the Major Quaternary Faults in Alborz-Central Iran Border Zone, from the East of Tehran to the East of Semnan. Journal of Geosciences, Geological Survey of Iran, 15, 184-188.

[49] Poroohan, N., Pourkermani, M. and Arian, M. (2013) An Assessment of Relationship in F-Parameter and Paleostress Fields in Heterogeneous Lithologies: Roudbar Area (Northwest of Iran). Australian Journal of Basic \& Applied Sciences, 7, 933-942.

[50] Poroohan, N., Poukermani, M. and Aryan, M. (2009) An Assessment on Correlations of Seismotectonic Parameters Preceding and Following Roudbar-Manjil Earthquake (Gilan, North of Iran). Australian Journal of Basic \& Applied Sciences, 3, 2643-2652.

[51] Farrokhnia, A. R., Pirasteh, S., Pourkermani, M. and Arian, M. (2011) Geo-Information Technology for Mass Wasting Hazard Zonation: Central-west Alborz-Iran. Disaster Advances, 4, 24-33.

[52] Khavari, R., Ghorashi, M. and Arian, M. (2009) Assessment of Relative Active Tectonics, South Central Alborz (North Iran). EGU General Assembly Conference Abstracts, 11, 1137. 
[53] Sorbi, A., Arian, M. and Pourkermani, M. (2009) The Movement Potential Evaluation of the Major Quaternary Faults in Tehran Quadrangle. Journal of the Earth, 19, 176-182.

[54] Feizi, F. and Arian, M. (2006) The Classification Of Thrust Fronts in The Alborz-Central Iran Border Zone from the East of Varamin to the East of Semnan. Journal of Sciences, 16, 75-87.

[55] Arian, M, and Feizi, F. (2005) Application of Geomorphic Indices to the Assessment of Relative Tectonic Activity Levels in the Alborz-Central Iran Border Zone the Alborz-Central Iran Border Zone (from the East of Varamin to the East of Semnan). Journal of Sciences (Islamic Azad University), 15, 378-403.

[56] Arian, M. and Pourkermani, M. (2004) Structural Significance of North Semnan and Attary Faults in Alborz-Central Iran border zone. Journal of Sciences (Islamic Azad University), 14, 4551-4569.

[57] Arian, M. and Pourkermani, M. (2005) Cenozoic Diastrophism and Deformational Events in the Southern Flank of Central-East Alborz. Journal of Faculty of Earth Sciences, Shahid Beheshti University, 10, 43-51.

[58] Arian, M., Pourkermani, M., Qorashi, M. and Ghasemi, M.R. (2003) North Semnan Fault System and Its Role on Basin Division. 8th symposium of Geological Society of Iran, 2, 11-17.

[59] Pourkermani, M. and Arian, M. (2001) Structural Geomorphology of Northeastern Kurdistan, Sistan and Baluchestan University. Journal of Humanities, 7, 37-48.

[60] Mardani, Z., Ghorashi, M. and Arian, M. (2011) Geomorphic Signatures of Active Tectonics in the Talaghan Rud, Shah Rud and Sefidrud Drainage Basins in Central Alborz, Niran. Geosciences, 20, 159-166.

[61] Sorbi, A., Arian, M. and Pourkermani, M. (2011) The Application of Geomorphic Indices to the Assessment of Relative Tectonic Activity Levels in Tehran Quadrangle. Journal of the Earth, 6, 1-9.

[62] Khavari, R., Ghorashi, M., Arian, M. and Khosrotehrani, K. (2010) Geomorphic Signatures of Active Tectonics in the Karaj Drainage Basin in South Central Alborz, Niran. Geosciences Scientific Quarterly Journal, 19, 67-74.

[63] Javadi Mousavi, E. and Arian, M. (2015) Tectonic Geomorphology of Atrak River, NE Iran. Open Journal of Geology, 5, 106-114. http://dx.doi.org/10.4236/ojg.2015.53010

[64] Nouri, R., Jafari, M.R., Arian, M., Feizi, F. and Afzal, P. (2013) Correlation between Cu Mineralization and Major Faults Using Multifractal Modelling in the Tarom Area (NW Iran). Geologica Carpathica, 64, 409-416. http://dx.doi.org/10.2478/geoca-2013-0028

[65] Nouri, R., Jafari, M.R., Arian, M., Feizi, F. and Afzal, P. (2013) Prospection for Copper Mineralization with Contribution of Remote Sensing, Geochemical and Mineralographical Data in Abhar 1:100,000 Sheet, NW Iran. Archives of Mining Sciences, 58, 1071-1084. http://dx.doi.org/10.2478/amsc-2013-0074

[66] Nouri, R., Afzal, P., Arian, M., Jafari, M. and Feizi, F. (2013) Reconnaissance of Copper and Gold Mineralization Using Analytical Hierarchy Process (AHP) in the Rudbar 1:100,000 Map Sheet, Northwest Iran. Journal of Mining and Metallurgy A: Mining, 49, 9-19.

[67] Arian, M. and Nouri, R. (2015) Lineament Tectonics and Mineralizatin in Tarom Area, North Iran. Open Journal of Geology, 5, 115-124. http://dx.doi.org/10.4236/ojg.2015.53011

[68] Feizi, F. and Arian, M. (2011) The Role of Structural Controllers in Geneses of Copper Deposits in 1:50000 Map of Saiin Qaleh. Journal of Sciences, 21, 1-10.

[69] Bahiraee, S, Arian, M., Qorashi, M. and Solgi, M. (2015) The Movement Potential Evaluation of the Mosha Fault (the West of Firoozkuh to the Shahrestanak). Geosciences, 24, 123-126.

[70] Bagha, N., Ghorashi, M., Arian, M., Pourkermani, M. and Solgi, A. (2015) Neotectonic Analysis of Mosha-North Tehran Fault Zone, Based on Morphotectonic Features, Central Alborz, Northern Iran. Geosciences, 24, 41-52.

[71] Arian, M., Toudeshki, V.H. and Noroozpour, H. (2011) Active Tectonics of Qezel Ozan River Basin, NW Iran. Journal of Applied Environmental and Biological Sciences, 1, 291-295.

[72] Housini Toudeshki, V., Pourkermani, M., Arian, M. and Khosrotehrani, K.H. (2011) Influence of Structures on the Ghezel Ozan River. Geosciences, 21, 55-60.

[73] Housini Toudeshki, V. and Arian, M. (2011) Morphotectonic Analysis in the Ghezel Ozan River Basin, NW Iran. Journal of Geography and Geology, 3, 258-260. http://dx.doi.org/10.5539/jgg.v3n1p258

[74] Keynezhad, A., Pourkermani, M., Arian, M. and Saeedi, A. (2011) Dynamic Analysis of Fractures in North of TorudMoalleman Area (Central Iran, East South of Damghan). Geosciences, 20, 3-16.

[75] Arian, M., Pourkermani, M., Sistanipour, A. and Noroozpour, H. (2011) Kinematic Significance of Fold- and FaultRelated Fracture Systems in the Rafsanjan's Northeast Highlands (Central Iran). Journal of Basic and Applied Scientific Research, 1, 3398-3406.

[76] Arian, M., Pourkermani, M., Sistanipour, A. and Noroozpour, H. (2011) Seismicity and Fault Segmentation of BafqBaghin Fault System (Central Iran). Journal of Applied Environmental and Biological Sciences, 1, 382-396. 
[77] Javadi Mosavi, E., Arian, M., Ghorashi, M. and Nazemi, M. (2012) Measurments of Geomorphic Indices in Tabas Area. Journal of the Earth, 7, 213-225.

[78] Arian, M. (2010) Earthquake-Fault Hazard Investigations in the Kerman Quadrangle. Journal of Sciences (Islamic Azad University), 19, 176-182.

[79] Javadi Mosavi, E. and Arian, M. (2015) Active Tectonics of Tabas Area, Central Iran. Open Journal of Geology, 5.

[80] Alizadeh, H., Arian, M., Lotfi, M., Ghorashi, M. and Ghorbani, M. (2015) Determination of Porphyry Copper Deposit Locations Using Photo Lineament Factor in Northern Parts of the Dehaj-Sardoiyeh Belt. Geosciences, 24, $247-252$.

[81] Jamalian Daryani, N., Arian, M. and Rashidnezhad Omran, N. (2015) Economic Tectonics of Copper in the ArdestanKahang Area, Central Iran by Remote Sensing. Open Journal of Geology, 5.

[82] Aghanabati, A. (2004) Geology of Iran. Geological Survey of Iran, Tehran, 586.

[83] Arian, M. (2010) Applied Seismotectonics. Farazamin Press, Tehran, 304 p. 